\title{
Synthesis of habitat restoration impacts on young-of-the- year salmonids in boreal rivers
}

\author{
Maare Marttila (1D - Pauliina Louhi - Ari Huusko - Teppo Vehanen • \\ Aki Mäki-Petäys · Jaakko Erkinaro · Jukka Tapani Syrjänen · Timo Muotka
}

Received: 10 April 2018/Accepted: 8 March 2019/Published online: 4 May 2019

(C) The Author(s) 2019

\begin{abstract}
River restoration offers the potential to enhance biological integrity, often measured as fish population changes. We used a meta-analytical approach to synthesize density responses to in-stream habitat restoration by young-of-the year (YOY) brown trout and Atlantic salmon in 28 rivers (overall 32 restoration projects) in Finland. We also examined which local and watershed-scale factors most influenced restoration success. Finally, we conducted an expert survey to obtain an independent estimate of a
\end{abstract}

Electronic supplementary material The online version of this article (https://doi.org/10.1007/s11160-019-09557-z) contains supplementary material, which is available to authorized users.

M. Marttila · P. Louhi · A. Mäki-Petäys · J. Erkinaro Natural Resources, Natural Resources Institute Finland (Luke), Oulu, Finland

M. Marttila · P. Louhi · T. Muotka

Ecology and Genetics Research Unit, University of Oulu, Oulu, Finland

Present Address:

M. Marttila $(\bowtie)$

Lapland Centre for Economic Development, Transport and Environment, Rovaniemi, Finland

e-mail: maare.marttila@ely-keskus.fi

J. T. Syrjänen

Department of Biological and Environmental Science,

University of Jyväskylä, Jyväskylä, Finland sufficient density enhancement for restoration to be considered successful. Despite strong context-dependency, habitat restoration had an overall positive effect on YOY salmonid density. When compared to target levels derived from the expert survey, density responses mainly reached the minimum expected success rate, but remained short of the level considered to reflect distinct success. Variability in restoration responses of trout was linked mainly to river size, predominant geology, water quality and potential interspecific competition (trout vs. European bullhead). Fishing mortality tended to obscure positive effects of restoration and stocking by YOY fish affected negatively trout's response to restoration,

T. Muotka

Freshwater Centre, Finnish Environment Institute (SYKE), Helsinki, Finland

A. Huusko

Natural Resources, Natural Resources Institute Finland

(Luke), Paltamo, Finland

T. Vehanen

Natural Resources, Natural Resources Institute Finland

(Luke), Helsinki, Finland 
supporting a shift towards self-sustainable schemes in fisheries management. These results imply that habitat restoration is a useful approach for improving the ecological and conservational status of salmonid populations in boreal rivers. To further improve the success rate, and thereby public acceptance, of restorations they need to be complemented by other management measures that enhance the potential for the recovery of threatened salmonid populations.

Keywords Atlantic salmon - Brown trout - Habitat improvement · Juvenile salmonids · Meta-analysis . River restoration

\section{Introduction}

River restoration is undertaken worldwide to restore degraded habitats, ecosystem processes, biotic communities and the services they provide. Traditionally, restoration has been species-driven, recreating channel forms believed to be favorable for a particular species or species group (Clarke et al. 2003; Palmer et al. 2010). In-stream habitat restoration then aims at increasing habitat availability for the target species, potentially enhancing fish productivity and reproduction, particularly of the declining salmonid populations (Roni et al. 2008; Stewart et al. 2009; Koljonen et al. 2012).

Salmonid fishes are widely regarded as indicators of stream restoration success (Roni et al. 2008). For instance, almost two-thirds of project managers in Washington State reported some type of salmon survey or count as the primary measure for evaluating their projects, and the top four biological measures were all salmonid related (Bash and Ryan 2005). Although the nature of evaluation data varies widely (Bash and Ryan 2005), it typically includes some type of monitoring, results of which often remain in grey literature or completely unpublished (but see Roni and Quinn 2001; Louhi et al. 2016). The synthesis of these data would provide valuable knowledge of restoration success and the factors affecting it (Stewart et al. 2009; Thomas et al. 2015).

Previous studies on in-stream restoration success have generally reported an increase in streambed and flow diversity (e.g. Muotka and Syrjänen 2007; Marttila et al. 2016a; Poppe et al. 2016) and salmonid rearing habitat (e.g. Korsu et al. 2010; Koljonen et al. 2012). However, studies focusing on salmonid reproductive success and juvenile abundances have shown highly variable responses. For example, Stewart et al. (2009) argued that the high variability of salmonid responses does not support widespread use of instream restoration structures, particularly in larger streams. In a review from northern Europe, Nilsson et al. (2015) showed that only one of the five papers that studied fish populations demonstrated a positive response to in-stream restoration. Similarly, Luhta et al. (2012) found slightly positive, but streamspecific effects on the density of young-of-the-year (YOY) brown trout. In contrast, Whiteway et al. (2010) and Roni et al. (2008) concluded that in-stream habitat improvement generally benefits juvenile salmonids, although the responses vary widely among species and life stages.

The inconsistency of biological responses results partly from differences in habitat enhancement practices (Palm et al. 2007; Louhi et al. 2016) but it also raises the question of whether other regional and local factors might enhance or constrain the biotic recovery of restored sites (Palmer et al. 1997; Muhar et al. 2016). Environmental variables are linked to biological productivity at variable spatial scales and may therefore shape the restoration outcome (Palmer et al. 1997). Properties of the surrounding catchment (e.g. geomorphology and river basin size) influence instream conditions (discharge, water temperature and chemistry, sedimentary processes and input of allochthonous material; Foldvik et al. 2017) which in turn play an important role in defining whether a restoration project meets its ecological goals. Species interactions and fishing mortality may also alter salmonid densities and overwhelm any positive effects of restoration (Palmer et al. 1997; Whiteway et al. 2010). Although several studies have emphasized the potential importance of these factors (Roni et al. 2008; Bernhardt and Palmer 2011), tests of their relative role based on extensive field data are largely missing (Kail et al. 2012; Lorenz and Feld 2013).

In Fennoscandia, the earliest stream restoration attempts took place about 40 years ago, with the aim of improving the spawning and nursery areas for salmonids, particularly brown trout (Salmo trutta) and Atlantic salmon (Salmo salar), in rivers channelized for timber floating. More recently, improving the overall ecological status of rivers has become a key 
objective of restoration, endorsed by the implementation of the EU Water Framework Directive (WFD) and associated legal obligations. In Finland, 35\% of total river length still remains below the minimum goal of good ecological status (SYKE 2013). In many cases, achieving this goal requires habitat restoration that should lead to a measurable increase in ecological quality. Prioritizing restoration efforts requires better understanding of their potential to improve river status (Lorenz and Feld 2013).

The aim of this study was to provide a more complete understanding of the success (or lack of it) of in-stream restoration in enhancing juvenile salmonid densities and of the factors that influence restoration success. Instead of assessing restoration responses on a case-by-case basis, our study synthesizes data from multiple restoration projects. We focused on YOY fish because their occurrence and densities are considered to indicate successful reproduction and fry survival (Lorenz et al. 2013). Our study focuses on the two salmonid species (brown trout; Atlantic salmon) important in Finnish streams and rivers but the results should be useful for fisheries managers in other boreal streams where largely similar techniques have been used for salmonid habitat enhancement. By using an extensive electrofishing database, we examined (1) whether restoration enhanced juvenile salmonid densities; (2) whether these two species with partly different habitat requirements (see Armstrong et al. 2003; Jonsson and Jonsson 2011) responded differently to similar restoration measures, (3) whether these improvements, if any, were considered sufficient by stream managers and fisheries experts, and (4) which in-stream and watershed-scale factors influenced salmonid responses to restoration.

\section{Materials and methods}

Study sites and study design

The dataset consisted of electrofishing surveys collected by our research partners in 28 rivers across 1978-2014. We included all surveys that provided data on salmonid densities for at least 2 years before and 2 years after restoration for a given site (overall number of restoration sites 88, a total of 1196 electrofishing surveys; Table S1). Time between the first and the last sampling year for a site varied from 6 to 33 years. The rivers are located in 17 watersheds across Finland $\left(60^{\circ}-68^{\circ} \mathrm{N}, 22^{\circ}-30^{\circ} \mathrm{E}\right)$ and they are either medium-sized (river basin size $100-1000 \mathrm{~km}^{2}$, 15 rivers) or large (1000-10,000 km $\mathrm{km}^{2}, 12$ rivers) lowland rivers, with one small river $\left(29.8 \mathrm{~km}^{2}\right)$ being also included. Drainage areas of the study rivers were dominated by peatland ( 8 rivers), mineral soil (17 rivers) or clay (3 rivers).

Hydromorphological degradation of the study sites was mainly caused by channelization for timber floating between the late nineteenth and mid-twentieth century. Rivers were straightened and narrowed, and boulders were removed from the channel, to facilitate timber floating (Nilsson et al. 2015; Syrjänen et al. 2018). Our dataset represents typical Fennoscandian running water habitats, including a wide environmental gradient in terms of size, water chemistry, stream gradient and catchment land use (mainly forestry) intensity, excluding only the smallest headwater streams $(<5 \mathrm{~m}$ wide) where timber floating was not practiced.

\section{Restoration measures}

As road transport of timber became economically feasible, timber floating largely ceased by the end of the 1970s. Soon thereafter, the first efforts were launched to restore the structural complexity of the rivers. To date, the majority of channelized rivers has been restored, in some cases more than once (Nilsson et al. 2015; Syrjänen et al. 2018). Usually this means returning boulders back into the river and adding instream structures, such as boulder dams and flow deflectors, to modify the flow and scour patterns. In addition, side channels are re-opened to increase the availability and connectivity of riverine habitats, providing more refuge areas for juvenile salmonids during adverse flow conditions (Yrjänä 1998; Nilsson et al. 2005). Also spawning gravel is routinely added in suitable places (in terms of water depth and current velocity) immediately after restoration to enhance the establishment of self-sustaining salmonid populations. In Finland, restoration projects usually target the entire main stem of river networks, with the activities focusing mainly on riffle and run sections of the rivers. Accordingly, most of the projects included in our study aimed at restoring all, or at least several, riffle-pool sequences within a river. 
Study species and estimation of juvenile densities

Brown trout was the target species of restoration in most of our study rivers $(n=27$, Table $S 1)$ whereas salmon was the main target species in only seven rivers (Table S1). Populations of Atlantic salmon and brown trout included in our study contain both searunning and freshwater populations. Both species belong to the 2010 Red List of Finnish Species and are classified as vulnerable to critically endangered (Rassi et al. 2010). Originally, salmon occurred in 20 rivers along the Finnish Baltic coast, but nowadays indigenous, self-sustaining salmon stocks are only found in rivers Tornionjoki and Simojoki (HELCOM 2011). Brown trout is distributed throughout Finland but its numbers have decreased drastically, and original, selfsupporting migratory stocks are rare. Migratory and resident trout may occur and reproduce within the same river system (Huusko et al. 2018) but their exact proportions in any specific population are unknown to us.

Fish data were collected in wadeable riffles following the Finnish electrofishing standard (Vehanen et al. 2013). The area of an electrofishing site was typically $100-300 \mathrm{~m}^{2}$ and data for replicate sites, if any, within a river section were pooled. Fish sampling focused on riffles because several studies in the same geographical area have shown that while larger fish tend to occupy deeper stream pools, the youngest size classes of both brown trout (Mäki-Petäys et al. 1997) and Atlantic salmon (Mäki-Petäys et al. 2005) are mainly found in riffle sections of rivers. An increased fish density in the restored study sites might reflect behavioural responses by fish (immigration to the best available habitats) rather than demographic responses within a restored reach. However, in another study (Syrjänen et al. 2014), we counted the number of spawning redds in eight of the trout rivers included in this survey, and about $60 \%$ of the electrofishing sites in these eight rivers contained redds with eggs. In the rest $40 \%$ of the sites, redds were observed within tens of metres from the electrofishing sites. We therefore believe it is safe to assume that the wild YOY fish in our electrofishing catches had mainly emerged within the same river section.

Fish densities were counted from the raw data or compiled from reports. If a site was fished by multiplepass removal, catchability values were used (Table S1). For one-pass method, fish densities (individuals $/ 100 \mathrm{~m}^{2}$ ) represented a direct catch or were generated using a river-specific or regional catchability (see Junge and Libosvarsky 1965). As we focused on density responses within a river, it was important to ensure that the estimation method was consistent across years within a river, whereas methodological differences between rivers should not bias our results (Whiteway et al. 2010; Thomas et al. 2015). Electrofishing methods were always the same before and after restoration and, in most cases, surveys before vs. after were conducted by the same field crew.

Our synthesis of YOY density responses was based on project-level data. A 'project' was defined as a compilation of restoration efforts within the same river and time period. If different sites within a river were restored at different times (i.e. $\geq 5$ years between restoration efforts), they were considered as distinct projects (identified with different letters in Table S1).

\section{Assessing restoration success: expert opinion}

One of our aims was to examine whether the restoration-induced increase in YOY densities (if any) was sufficient to designate a restoration project successful from the salmonid fisheries perspective. Therefore, we conducted a questionnaire survey among the key Finnish water managers and fisheries/ environmental consultants, both governmental and private, to identify appropriate target levels for YOY salmonid densities. An e-mail survey was sent to 25 recipients in different environmental agencies across Finland. They were selected to our survey because of their experience and expertise in river restoration and/ or monitoring of fish densities in different regions. We asked the recipients to (1) define the minimum improvement in YOY salmonid (salmon and/or trout) density needed to designate a restoration effort successful, and (2) to shortly describe the restoration projects they have been involved in. Seventeen recipients replied to our survey, the response rate being $68 \%$. The two most frequently stated indicators of success, representing different levels of expected improvement, were: (1) $1.1 \times$ pre-restoration density (i.e. $10 \%$ increase; often defined as 'any improvement indicates success'), and (2) $2 \times$ pre-restoration density ('distinct success'). 
Potential factors affecting restoration outcome

The following factors that might potentially regulate restoration success were compiled for each project and were associated with the electrofishing data (Table S1):

(1) Recovery time, classified into four phases: before restoration, 1-4 years (short term), 5-8 years (middle term) and $>8$ years (long term; up to 19 years) after restoration.

(2) Latitude as an indicator of geographical location.

(3) River basin size: medium $100-1000 \mathrm{~km}^{2}$ and large $1000-10,000 \mathrm{~km}^{2}$ (obtained from national database HERTTA managed by the Finnish Environment Institute, http://www.syke.fi/enUS/Open_information).

(4) Predominant geology: peatland or mineral soils (HERTTA).

(5) Water quality variables calculated as average values across the most recent 10 years (HERTTA; Tables SI and S2). Data on total phosphorus (totP) and $\mathrm{pH}$ were from the whole calendar year, whereas oxygen saturation $\left(\mathrm{O}_{2} \%\right)$ was recorded for the winter months only (November to April). The water quality variables included in the analysis were assumed to potentially influence egg survival during the winter and thus YOY densities (Crisp 1996).

(6) The presence of migratory obstacles downstream of a restored site; indicator of habitat connectivity.

(7) Annual data on stocking of eggs, alevins and YOY. If no stocking was conducted, all observations of YOY were assumed to indicate natural reproduction.

(8) Fishing pressure: fishing forbidden or only catch-and-release (CR) fishing allowed; fishing allowed on license.

(9) Species interactions, density of a potential predator, burbot (Lota lota) and a competitor, European bullhead (Cottus gobio); data on these species were available for 21 rivers.

We used annual data on migratory obstacles, stockings, fishing pressure and species interactions, thus taking into account possible changes in these variables during the monitoring period.
Unfortunately, most projects did not include measurements of stream habitat structure so we were unable to include it as an explanatory variable in our meta-analysis. Nevertheless, we have made such measurements in several previous projects, the very consistent outcome being that the way river restoration is being conducted in Finland considerably enhances in-stream habitat heterogeneity (e.g. Muotka and Syrjänen 2007; Vehanen et al. 2010; Marttila et al. 2016a; see also similar results from Swedish streams, Polvi et al. 2014).

\section{Statistical analysis}

To synthesize restoration responses between two 'treatments' (before vs. after restoration) from multiple projects ( $n=30$ for trout and $n=7$ for salmon), we used random effects model with restricted maximum likelihood estimator (REML; function rma in package metafor; Viechtbauer 2010). REML is recommended when differences in sampling methods and sample characteristics may introduce variability among true effects (Viechtbauer 2010). Mean difference between study treatment means (after-before mean densities) was compiled from each study and used to calculate the grand mean effect size and its bootstrapped $95 \%$ confidence intervals, separately for trout and salmon. Sample size (i.e., number of sampling sites in a project) was always equal between the two 'treatments', and the mean values were counted from the site-level data. We used an unweighted meta-analysis, because the use of empirically-based weighting in random-effects meta-analysis has been questioned recently (Shuster 2010; Shuster et al. 2010). There is also often ecological justification for using unweighted meta-analysis (e.g. Gruner et al. 2017). In our case, weighted analysis would have given undue emphasis on studies with very low salmonid numbers both before and after restoration, resulting in spuriously precise estimates of effect size (see Stewart 2010).

Models on the potential factors affecting restoration outcome were only constructed for trout because of the low number of salmon rivers $(n=7)$. YOY trout densities in medium and large-sized rivers $(n=26)$ were analysed by fitting a generalized linear mixed model with a negative binomial distribution (function glmer.nb in package lme4 in R; Bates et al. 2014). In our basic model, treatment (before and after 
restoration) was included as a fixed factor, and sites nested within rivers and years since restoration (before and after) as random effects. For all models, random effects were evaluated according to Zuur et al. (2009) and were found to improve fit of the model (comparisons of log-likelihoods). Comparisons were made either against the before-restoration period (for variables with the same value both before and after restoration; i.e., river basin size and predominant geology) or against the before-period $\times$ a variable (presence of migratory obstacles, fishing pressure, stockings, presence of European bullhead or burbot. For water chemistry variables and latitude, interaction was not included in the models to avoid any bias caused by varying numbers of fishing surveys in before vs after periods.

Unlike other GLMM's, the model for recovery time was constructed for both salmon and trout. The model included the four time periods (before restoration, short, middle and long after restoration) as fixed factor, and sites nested within rivers and calendar year of restoration as random effects. Density responses between time periods were compared using each relevant time period as an intercept.

To relate fish density responses to expert opinions about restoration success we used a subset of 13 trout projects with reasonable pre-restoration densities ( $>$ one individual per $100 \mathrm{~m}^{2}$ ). We thus excluded sites where trout were only sporadically observed before restoration. The expected response rates (minimum level of improvement; distinct success) derived from expert opinions were made commensurate with our density data by multiplying mean pre-restoration densities of each project by 1.1 or 2 , respectively.

\section{Results}

Overall effects of restoration on salmonids

The overall effects of restoration were positive for both species, but the response was significant only for trout. Mean effect sizes (calculated as mean difference across studies between after-before densities) were, however, closely similar: $4.32(95 \% \mathrm{CI}=1.14-7.50$, $\mathrm{n}=30$, ) for trout and $5.06(95 \% \mathrm{CI}=-2.28-12.39$, $\mathrm{n}=7$ ) for salmon (Fig. 1). The mean density of young-of-the-year brown trout was 3.09 fish $100 \mathrm{~m}^{-2}$ (range: 0-19) before restoration and $7.14(0-31)$ after

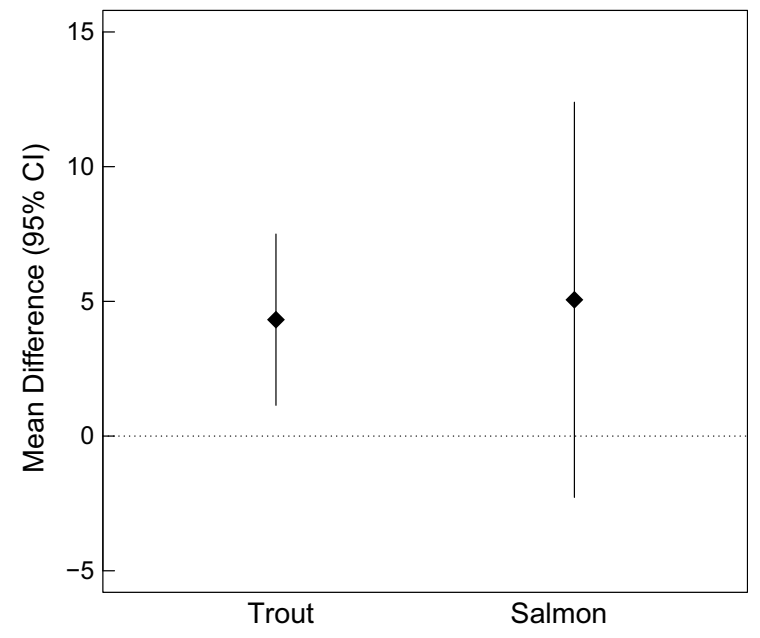

Fig. 1 Mean effect sizes, calculated as mean difference between study treatment means (after-before mean densities $\pm 95 \%$ bootstrap confidence intervals) for the effect of restoration on YOY brown trout $(\mathrm{n}=30$ restoration projects) and Atlantic salmon $(\mathrm{n}=7)$ densities

it. Corresponding values for Atlantic salmon were 1.23 (range: $0-8)$ and $5.66(0-15)$ fish $100 \mathrm{~m}^{-2}$, respectively. Thus, we can say with $95 \%$ confidence (assuming a random effects model) that the effect of restoration on trout densities was at least slightly positive, whereas confidence limits for salmon overlap zero and therefore the restoration impact, cannot be considered significant. The trout response was positive (although not always significantly so) in 23 and negative in seven projects (Fig. 2a). Salmon response was positive in six projects and negative in one (Fig. 2b). The test for heterogeneity suggested no heterogeneity among true effects (trout: $Q=19.22$, $d f=29, \quad p=0.916 ; \quad$ salmon: $\mathrm{Q}=4.15, \quad d f=6$, $p=0.656)$.

Level of improvement in relation to experts' expectations

When the overall improvement in trout densities was compared to that expected by stream managers and other experts, the minimum success rate $(1.1 \times$ prerestoration density; mean expected effect size $=0.73$ ) was mostly exceeded ( 8 projects exceeded, 5 did not). However, the level considered as distinct success $(2 \times$ pre-restoration density; mean expected effect size $=7.27$ ) was mostly not achieved (4 projects achieved, 9 did not). 
Local and regional determinants of salmonid response

GLMM results indicated that salmon responses did not vary among the three post-restoration time periods. For trout, densities recorded shortly after restoration were somewhat higher than in the two subsequent periods (Table 1), whereas middle and long-term periods did not differ from each other.

Several environmental variables modified the responses of YOY trout to restoration. First, trout density response was more positive in mid-sized than in large rivers (Table 2). Trout response was also related to predominant geology and was less positive in rivers draining peatland-dominated catchments than in those surrounded by mineral soils. Compared to rivers draining mineral soils, rivers on peatlanddominated catchments had higher concentration of phosphorus and lower levels of $\mathrm{pH}$ and wintertime $\mathrm{O}_{2}$ saturation (Table S2). Total phosphorus was negatively and wintertime oxygen saturation positively associated with trout density responses (Table 3). YOY trout response to restoration was also related to site location, with more positive responses in southern than northern Finnish rivers (Table 3).

Our results also suggested that fishing regulations may influence trout responses to restoration. Trout density responses were more positive at sites where trout fishing was completely prohibited or only catchand-release fishing was allowed compared to sites where fishing was allowed on license (Table 2). The effect of fishing regulations was not very strong, however, as the interaction only bordered at significance. We also found a negative interaction between trout density response and stocking of alevins/YOY, indicating that attempts to increase density through artificial colonization had an opposite effect. Stocking of eggs had no effect on trout responses (Table 2).

Restoration did not change densities of burbot ( $\mathrm{z}=-1.656, p=0.098)$, and neither did this piscivore affect the responses of trout to restoration (Table 2). European bullhead responded positively to restoration $(\mathrm{z}=2.082, p=0.037)$ and its presence reduced the response of trout (Table 2).

\section{Discussion}

Stream restoration offers the potential to enhance biological integrity, often measured as fish population changes (Jungwirth et al. 2000). Our synthesis of instream restoration projects in Finland demonstrated a highly context-dependent, but on average positive effect of restoration on YOY salmonid density. The positive overall response was significant for brown trout, but not for Atlantic salmon. Also the previous synthesis by Roni et al. (2008) and Whiteway et al. (2010) showed that although in-stream habitat improvements were generally beneficial for juvenile salmonids, responses varied between species. Interestingly, Whiteway et al. (2010) suggested that Atlantic salmon responded more than did brown trout. In our study, the size and direction of the effect sizes showed that the two species responded almost similarly to restoration. The difference in statistical significance likely reflects differences in sample size: the lower number of salmon projects resulted in greater variation in effect size. While this mainly results from the low number of remaining salmon rivers, it is also possible that restoration designed to support juvenile trout may not serve the habitat requirements of Atlantic salmon equally well. Although the juvenile stages of the two species have largely similar habitat requirements, there are also important differences. For example, brown trout are known to prefer deeper stream areas with moderate to low water velocities, whereas young Atlantic salmon tend to occupy faster-flowing and shallower stream areas (Heggenes 1996; Armstrong et al. 2003). Also the scarcity of overwintering habitats may restrict salmon populations even if summertime rearing habitats are improved (Palm et al. 2007; Koljonen et al. 2012). Such species-specific differences in habitat use and preference need to be better incorporated into restoration designs in the future.

Whether restoration is considered successful relates partly to expectations by various interest groups (Marttila et al. 2016b); a failure for one can be a success for another (Baker and Eckerberg 2016). A prerequisite for evaluating whether restoration has been effective is that project goals have been accurately defined a priori (Miller et al. 2016). In this study, we conducted an expert survey to identify their definitions for success. Comparing the observed trout responses to expected response rates indicated that 
(A)

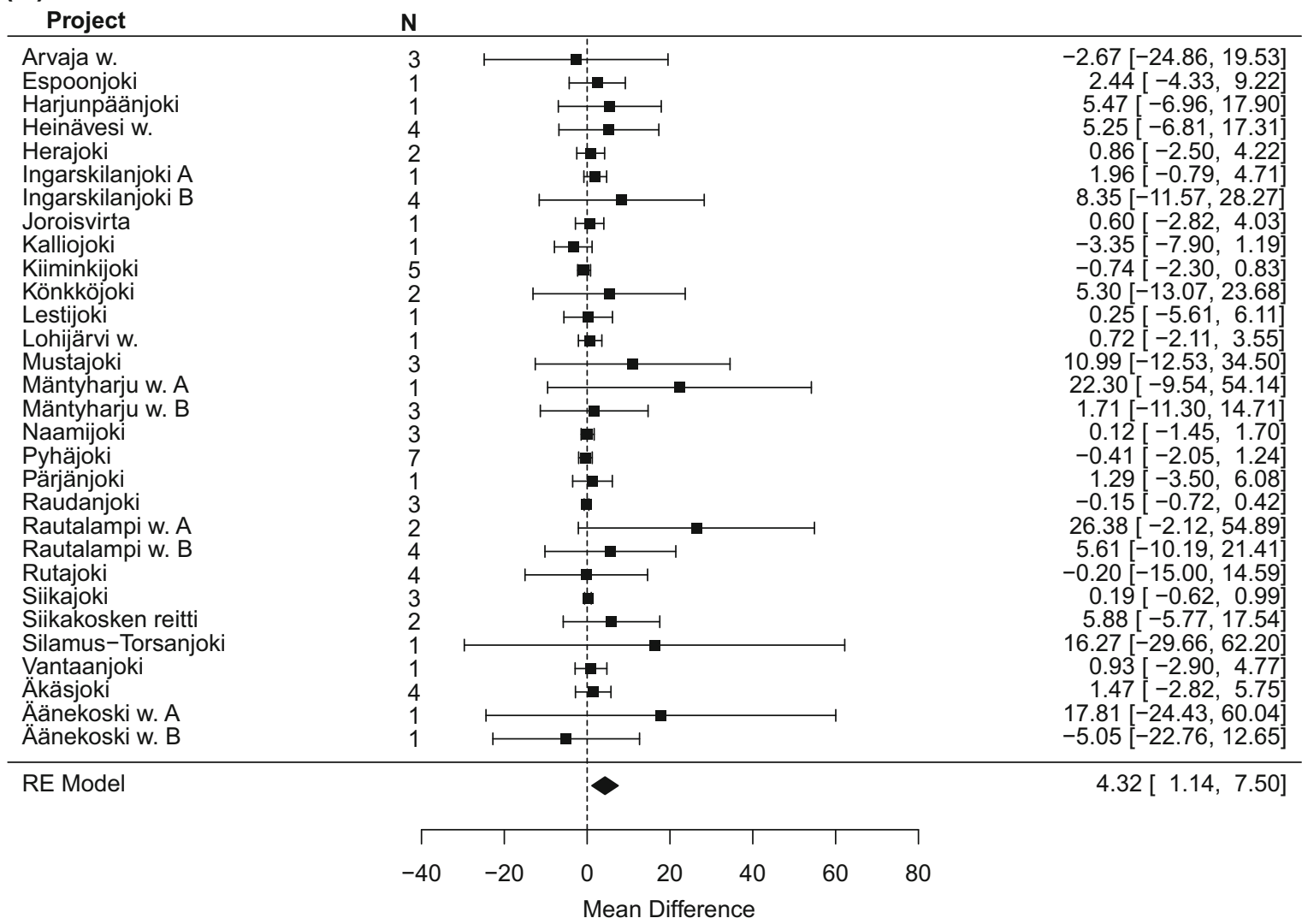

(B)

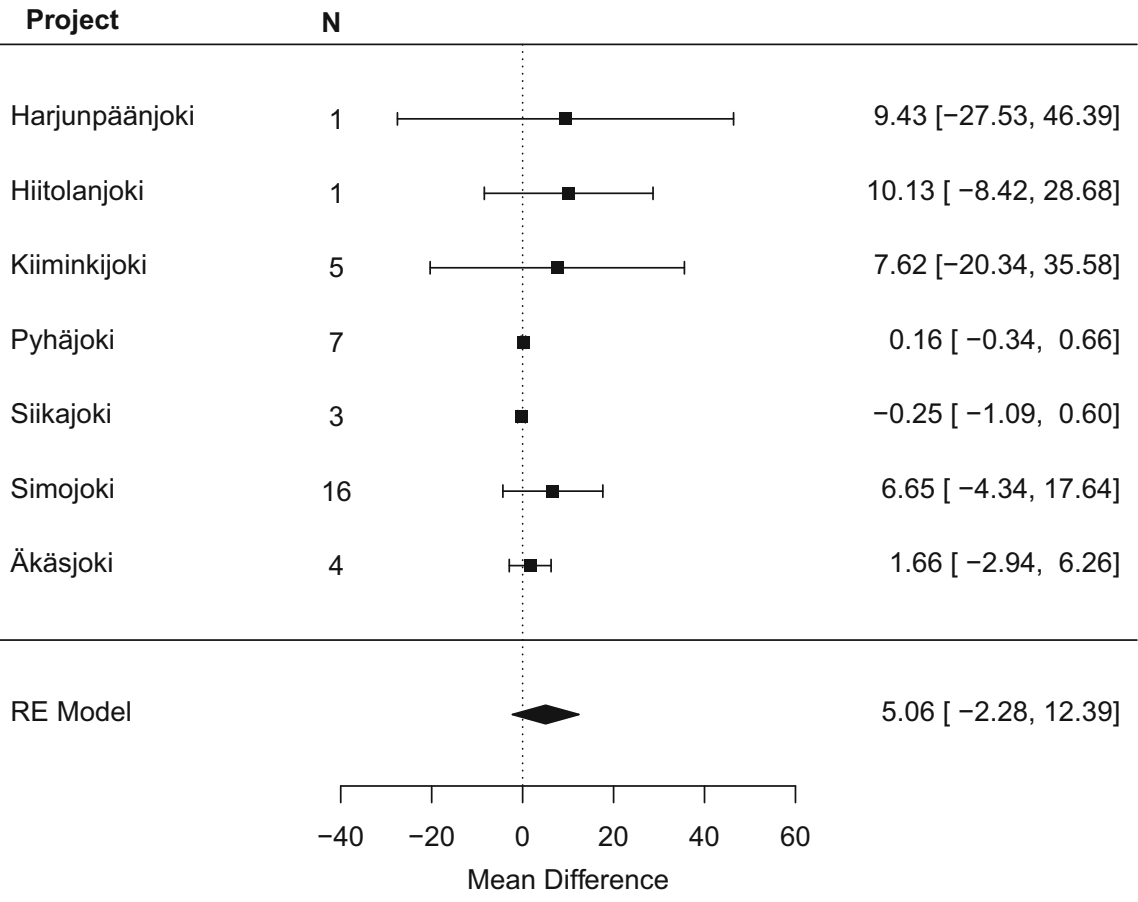


4Fig. 2 Forest plots showing the effect of in-stream habitat restoration on a brown trout density in 30 projects (w. = watercourse) and $\mathbf{b}$ on Atlantic salmon density in seven projects. 'Mean difference' refers to mean difference between study treatment means (after-before mean densities $\pm 95 \%$ bootstrap confidence intervals). Diamond illustrates the grand mean effect size (and its bootstrapped 95\% confidence intervals) calculated from project-specific mean differences. $\mathrm{N}=$ number of study sites within a project

restoration projects had largely reached the minimum success level, but remained short of distinct success. A few respondents expressed very high expectations for restoration, suggesting that a successful project should bring the fish population back to its natural, pre- channelization state ( $>30$ individuals $/ 100 \mathrm{~m}^{2}$ ). This highly ambitious goal was rarely achieved, as postrestoration trout densities remained mainly lower than those typically observed in near-pristine streams in Finland (Syrjänen et al. 2015). On the other end of the continuum, one respondent suggested that, for endangered populations, such as the landlocked form of Atlantic salmon and sea-running populations of brown trout (Rassi et al. 2010), even a slight increase is significant. Indeed, even low returns from restored reaches may contribute to the overall viability of a fish population (Waldman et al. 2016).

Studies reporting post-restoration recovery times of stream fishes are rare (Thomas et al. 2015). Our results

Table 1 Parameter estimates from the generalized linear mixed models examining differences in YOY salmonid densities between time periods (short after restoration vs before restoration, middle and long term after restoration)

\begin{tabular}{|c|c|c|c|c|c|c|c|c|}
\hline & \multicolumn{4}{|l|}{ Trout } & \multicolumn{4}{|l|}{ Salmon } \\
\hline & Estimate & SE & $\mathrm{z}$ value & $\mathrm{P}$ & Estimate & SE & $\mathrm{z}$ value & $p$ \\
\hline Intercept (Short) & 0.736 & 0.393 & 1.872 & 0.061 & 0.432 & 0.694 & 0.623 & 0.534 \\
\hline Before & -0.713 & 0.128 & -5.586 & $<0.001$ & -1.024 & 0.244 & -4.201 & $<0.001$ \\
\hline Middle & -0.377 & 0.165 & -2.278 & 0.023 & -0.138 & 0.297 & -0.465 & 0.642 \\
\hline Long & -0.395 & 0.165 & -2.39 & 0.017 & 0.028 & 0.434 & 0.064 & 0.949 \\
\hline
\end{tabular}

Significant $p$ values are in bold

Table 2 Results of generalized linear mixed models examining YOY brown trout responses to treatment $\times$ explanatory variable interactions ('treatment' referring to before vs. after restoration) Comparisons were made either against the beforerestoration period (explanatory variables with the same value both before and after restoration; i.e., river basin size and predominant geology) or against the before-period $\times$ a variable (presence of migratory obstacles, fishing pressure, stockings, presence of European bullhead or burbot). Only interaction terms are reported, as the main effects are uninterpretable under this design

\begin{tabular}{|c|c|c|c|c|c|}
\hline Source (intercept in brackets) & $\begin{array}{l}\text { Model } \\
\text { intercept }\end{array}$ & $\begin{array}{l}\text { Estimate for } \\
\text { treatment } \times \text { variable }\end{array}$ & SE & $\mathrm{z}$ value & $p$ \\
\hline Size: medium (vs. large) & -0.759 & 1.129 & 0.238 & 2.199 & $\mathbf{0 . 0 2 8}$ \\
\hline Geology: peat (vs. mineral) & 0.731 & -2.588 & 0.393 & -3.304 & $<0.001$ \\
\hline Obstacles: present (vs. absent) & 0.162 & -0.166 & 0.517 & 0.987 & 0.324 \\
\hline $\begin{array}{l}\text { Fishing pressure: forbidden/CR (vs. allowed on } \\
\text { license) }\end{array}$ & -0.355 & 0.888 & 0.288 & -1.882 & 0.06 \\
\hline \multicolumn{6}{|l|}{ Stockings } \\
\hline Eggs (vs. no stockings) & -0.05 & 0.674 & 0.486 & -0.386 & 0.70 \\
\hline Alevins/YOY (vs. no stockings) & -0.05 & -0.033 & 0.45 & -2.56 & 0.01 \\
\hline European bullhead & -2.256 & -0.916 & 0.025 & -3.823 & $<0.001$ \\
\hline Burbot & -1.265 & -0.324 & 0.241 & 1.761 & 0.078 \\
\hline
\end{tabular}

Significant $p$ values are in bold. See more details on explanatory variables in the text

${ }^{\mathrm{a}} \mathrm{CR}=$ catch-and-release fishing 
Table 3 Parameter estimates from the generalized linear mixed models examining effects of covariates on YOY trout density responses

\begin{tabular}{lcclrr}
\hline & Model intercept & Estimate for treatment & SE & z value & $p$ \\
\hline Latitude & -0.582 & -1.36 & 0.344 & -3.958 & $<\mathbf{0 . 0 0 1}$ \\
TotP & 0.818 & -0.038 & 0.019 & -2.024 & $\mathbf{0 . 0 4 3}$ \\
Winter- $\mathrm{O}_{2} \%$ & -0.191 & 0.832 & 0.304 & 2.735 & $\mathbf{0 . 0 0 6}$ \\
$\mathrm{pH}$ & -2.992 & 0.428 & 1.452 & 0.295 & 0.768 \\
\hline
\end{tabular}

Significant $p$ values are in bold

suggested that trout densities were higher immediately after restoration than during later phases. Similarly, Höckendorff et al. (2017) reported an initially high fish response that stabilized approximately 7 years after restoration. One explanation for fading trout responses could be a gradual deterioration of gravel beds after restoration (e.g. Marttila et al. 2016a). Louhi et al. (2016) reported that only long-term monitoring (up to 10-12 years) of trout densities revealed the success of in-stream habitat restoration while short-term monitoring ( 3 years post-restoration) of the same sites yielded less encouraging results (Vehanen et al. 2010). In any case, the inherently large interannual variability of salmonid populations (Roni et al. 2002; Muotka and Syrjänen 2007; Louhi et al. 2016) makes the detection of restoration responses challenging and requires monitoring that spans several fish generations (Kondolf and Micheli 1995; Roni et al. 2015). Some of our data spanned almost 20 years post-restoration, enabling us to examine the long-term trajectory of the restoration outcome. Although the year of restoration was considered as a random effect in our analyses, the fact that the recovery periods among our study rivers were not synchronized may have influenced our capacity to detect temporal trends.

The strongest positive responses for trout were recorded in mid-sized rivers. This finding supports the view that restoration is more challenging in larger rivers: the larger the river, the more complex are the environmental issues associated with the upstream drainage basin (National Research Council 1992). Similarly, Stewart et al. (2009) concluded that instream structures may be less effective in larger rivers than in smaller streams, whereas Whiteway et al. (2010) showed no difference in density responses between different-sized streams.
The weaker responses by trout in peatland-dominated river basins may be related to acidity caused by humic substances (Laudon and Buffam 2008). While the range of water quality variables at our study sites was typical of Finnish rivers, the use of mean values may have hindered us from detecting the lowest seasonal values that may have obscured restoration responses. Total phosphorus was negatively related to trout response, possibly indicating the limiting effect of even slight nutrient enrichment on the capacity of juvenile trout to respond positively to restoration. Several previous studies have concluded that instream habitat restoration is unlikely to be successful unless water quality is controlled at the watershed scale (e.g. Haase et al. 2013; Mueller et al. 2014; Roni et al. 2015). While poor water quality may have reduced the beneficial effects of habitat restoration in some of our study rivers, it is likely that water quality was mainly sufficient to allow positive development of salmonid populations.

We detected a geographical structure in trout responses to restoration, with trout densities responding more positively in southern than in northern Finnish rivers. Geographic patterns in restoration responses are likely interrelated to other natural and anthropogenic characteristics of the rivers addressed in this study. However, they may also stem from potential differences in restoration procedures and the time needed for biotic recovery (related to, for example, fish generation length) in different parts of the country.

Few previous studies have examined the effect of fishing pressure on restoration outcome (but see Gowan and Fausch 1996). We used river-specific information on fishing regulations as a proxy of fishing pressure. Our results suggest that fishing mortality may obstruct the positive effects of habitat restoration 
and stricter fishing regulations are needed to support population recovery (Binns 2004). The effect of fishing regulations remained relatively weak, however, possibly because of the low number of sites where fishing after restoration was either completely forbidden or only catch-and-release fishing was allowed. Habitat enhancement may trigger increased angler interest, causing intensified fishing pressure after restoration (Binns 2004), and migrating salmonids are exposed to fishing mortality also during the lake (or sea) phase (Syrjänen et al. 2018). Therefore, even when habitat restoration may seem to have failed, restoration may allow a higher success rate if constraints related to strong fishing pressure are mitigated (Bond and Lake 2003).

Recovering salmonid populations may be vulnerable to predators and competitors (Ward et al. 2008) and increased densities of predators may be associated with low recruitment of salmonids (Ward et al. 2008; Luhta et al. 2012). It remains unclear, however, if and how habitat restoration influences potential predators and competitors of juvenile salmonids (Nilsson et al. 2005). We did not find any effect of a potential predator (burbot) on salmonids, and neither did this species seem to benefit from restoration. Instead, European bullhead responded positively to restoration and its presence reduced the positive effect of restoration on trout. Brown trout and bullhead occupy partly similar niches and are therefore potential competitors. Previous studies have reported variable results on competitive interactions between bullhead and salmonids (Louhi et al. 2014, and references therein) but our results suggest that competition between these two species may be asymmetric, with bullhead limiting trout's response to restoration. Restoration efforts rarely target nonsalmonid fishes and any responses by these species to in-stream restoration are therefore poorly known. In one of the few exceptions, Roni (2003) examined the effects of large woody debris (LWD) on several benthic fishes, including two Cottus species, in 29 North American streams. Densities and mean lengths of the species examined did not differ between restored vs. reference reaches although the length of reticulate sculpin $(C$. perplexus) was positively related to the amount of LWD. Clearly, more research on the responses of nontarget fish species to stream habitat enhancement is needed.
In-stream restoration is often supported by stocking, also referred to as assisted colonization (Stoll et al. 2013). Although this is a controversial measure, its use may be justified for species with scattered distributions, particularly if the target species has disappeared completely from a river (Luhta et al. 2012; Stoll et al. 2013). In Finland, stockings of Atlantic salmon and migratory brown trout have been conducted for more than a century (Luhta et al. 2012; Syrjänen et al. 2015). Since stocking is often undertaken within a few years after restoration, it might seem an obvious explanation for the temporary post-restoration density increase of trout. However, stockings were either ineffective (eggs) or negatively related (alevins/YOY) to restoration outcome, thus supporting previous findings that the benefits of current stocking practices are moderate at best (Luhta et al. 2012; Syrjänen et al. 2015). High numbers of stocked YOY may attract predators (Ward and Hvidsten 2011) and cause density-dependent mortality during the parr stage (Einum et al. 2008), thus rendering stocking an ineffective or even detrimental tool for fisheries management. In the near future, we may see a paradigm shift in salmonid management whereby expensive stockings are replaced, either partly or entirely, with measures that address directly the factors that limit the recovery of threatened fish populations (Ministry of Agriculture and Forestry 2012).

Habitat restoration likely has a higher potential to improve local fish production if dispersal to and from the restored site is unrestricted (Gowan and Fausch 1996). However, trout response in our study was unrelated to downstream migratory obstacles. Stoll et al. (2013) noted that to test the importance of barriers appropriately information on passability, not simply presence, of migration obstacles is needed. They also found that the spatial extent of dispersal was surprisingly limited; species not present within $5 \mathrm{~km}$ up- or downstream of a restored reach were unlikely to colonize the site within a few years (Stoll et al. 2013). Unfortunately, information on the distance and abundance of source populations was unavailable for most of our study sites.

Assessing merely YOY density responses may lead to partial misinterpretation of the restoration outcome. For example, lack of spawners may prevent populations from reaching the full restoration potential. Furthermore, parr-to-smolt survival may vary between restored rivers, regardless of their potential for YOY 
recruitment. Previous studies have reported variable results among fish life stages (Roni et al. 2008), and some observations suggest that larger salmonids may in fact be more responsive to habitat restoration than are juveniles (Gowan and Fausch 1996; White et al. 2011). In boreal streams, main concerns are related to the lack of spawning and overwintering habitats (Palm et al. 2007; Koljonen et al. 2012; Marttila et al. 2016a). Indeed, better results could be achieved by using more variable restoration material, such as spawning gravel and wood. Particularly the addition of large wood may considerably enhance the rearing capacity of stream habitat for salmonid fishes (Jones et al. 2014), often resulting in better survival and higher abundance of salmonids in restored reaches (Johnson et al. 2005; Louhi et al. 2016; Thompson et al. 2018).

The overall amount of new habitat created through restoration was insufficiently reported and therefore was not considered in our density estimations. Koljonen et al. (2012) and Lepori et al. (2005) showed that restoration may increase the wetted width of a reach considerably (up to $40 \%$ ), thereby increasing habitat availability per reach (Korsu et al. 2010). Therefore, even if reach-scale density remains unaltered, total numbers of YOY trout may increase after restoration (Lepori et al. 2005; Nilsson et al. 2015).

Despite considerable context-dependency, our meta-analysis provides evidence that salmonid densities have generally benefitted from stream habitat restoration. This suggests that stream restoration has potential to enhance the recovery and conservation of salmonid populations. Density responses of brown trout reached the minimum success rate, but remained lower than what the experts perceived as distinct success. Restoration success was linked to watershedscale factors, such as water quality, geographical location and river size, as well as to fishing regulations and interspecific competition. Many of these factors have been highlighted in previous studies, but testing their role based on a meta-analytical approach is a novel contribution. Our study supports the notion that restoration is more likely to be successful if the watershed-scale context is considered. Finally, we emphasize that well-planned fisheries management, especially as it relates to fish stocking and fishing regulations both in the river and in feeding areas, is critical for the sustainable development of threatened migratory fish stocks.
Acknowledgements Open access funding provided by Natural Resources Institute Finland (LUKE). This study was supported by the Maj and Tor Nessling Foundation, Maa- ja vesitekniikan tuki ry and Academy of Finland (AKVA grant no. 263597). Electrofishing data were kindly provided by Natural Resources Institute Finland (Luke), Regional Centres for Economic Development, Transport and the Environment, Metsähallitus, University of Jyväskylä and fisheries/ environmental consults. We acknowledge H. Aulaskari, A. Eloranta, A. Haapala, J. Huhtala, L. Hyytinen, A. Huhmarniemi, A. Janatuinen, E. Jokikokko, M. Koivurinta, P-L. Luhta, K. Poikola, A. Saura, T. Sutela, M. Tapaninen, J. Tertsunen, T. Turunen, P. Valkeajärvi, V. Vähä and all others who made reports and data accessible and provided information on restoration sites. We also thank all the respondents of the expert survey as well as the two anonymous reviewers for constructive comments on a previous version of the manuscript.

Open Access This article is distributed under the terms of the Creative Commons Attribution 4.0 International License (http:// creativecommons.org/licenses/by/4.0/), which permits unrestricted use, distribution, and reproduction in any medium, provided you give appropriate credit to the original author(s) and the source, provide a link to the Creative Commons license, and indicate if changes were made.

\section{References}

Armstrong JD, Kemp PS, Kennedy GJA, Ladle M, Milner NJ (2003) Habitat requirements of Atlantic salmon and brown trout in rivers and streams. Fish Res 62:143-170

Baker S, Eckerberg K (2016) Ecological restoration success: a policy analysis understanding. Restor Ecol 24:284-290. https://doi.org/10.1111/rec.12339

Bash JS, Ryan CM (2005) Stream restoration and enhancement projects: is anyone monitoring? Environ Manag 29:877-885

Bates D, Maechler M, Walker S, Christensen RHB, Singmann H, Dai B (2014) Package 'Ime4'. R package version 1.1-7. http://lme4.r-forge.r-project.org/. Accessed 26 May 2017

Bernhardt ES, Palmer MA (2011) River restoration: the fuzzy logic of repairing reaches to reverse catchment scale degradation. Ecol Appl 21:1926-1931

Binns NA (2004) Effectiveness of habitat manipulation for wild walmonids in Wyoming wtreams. North Am J Fish Manag 24:911-921

Bond NR, Lake PS (2003) Local habitat restoration in streams: constraints on the effectiveness of restoration for stream biota. Ecol Manag Restor 4:193-198. https://doi.org/10. 1046/j.1442-8903.2003.00156.x

Clarke SJ, Bruce-Burgess L, Wharton G (2003) Linking form and function: towards an eco-hydromorphic approach to sustainable river restoration. Aquat Conserv Mar Freshw Ecosyst 13:439-450

Crisp DT (1996) Environmental requirements of common riverine European salmonid fish species in fresh water with particular reference to physical and chemical aspects. 
Hydrobiologia 323:201-221. https://doi.org/10.1007/ BF00007847

Einum S, Nislow KH, Reynolds JD, Sutherland WJ (2008) Predicting population responses to restoration of breeding habitat in Atlantic salmon. J Appl Ecol 45:930-938. https:// doi.org/10.1111/j.1365-2664.2008.01464.x

Foldvik A, Einum S, Finstad AG, Ugedal O (2017) Linking watershed and microhabitat characteristics: effects on production of Atlantic salmonids (Salmo salar and Salmo trutta). Ecol Freshw Fish 26:260-270. https://doi.org/10. 1111/eff.12272

Gowan C, Fausch KD (1996) Long-term demographic responses of trout populations to habitat manipulation in six Colorado streams. Ecol Appl 6:931-946. https://doi.org/10.2307/ 2269496

Gruner DS, Bracken MES, Berger SA, Eriksson BK, Gamfeldt L, Matthiessen B, Moorthi S, Sommer U, Hillebrand H (2017) Effects of experimental warming on biodiversity depend on ecosystem type and local species composition. Oikos 126:8-17. https://doi.org/10.1111/oik.03688

Haase P, Hering D, Jähnig SC, Lorenz AW, Sundermann A (2013) The impact of hydromorphological restoration on river ecological status: a comparison of fish, benthic invertebrates, and macrophytes. Hydrobiologia 704:475. https://doi.org/10.1007/s10750-012-1255-1

Heggenes J (1996) Habitat selection by brown trout (Salmo trutta) and young Atlantic salmon ( $S$. salar) in streams: static and dynamic hydraulic modelling. River Res Appl 12:155-169

HELCOM (2011) Salmon and sea trout populations and rivers in the Baltic Sea-HELCOM assessment of salmon (Salmo salar) and sea trout (Salmo trutta) populations and habitats in rivers flowing to the Baltic Sea. In: Baltic sea environment proceedings $126 \mathrm{~A}$

Huusko A, Vainikka A, Syrjänen JT, Orell P, Louhi P, Vehanen $\mathrm{T}$ (2018) Life-history of the adfluvial brown trout (Salmo trutta L.) in Eastern Fennoscandia. In: Lobón-Cerviá J, Sanz N (eds) Brown trout: biology, ecology and management. Wiley, Hoboken, pp 267-295

Höckendorff S, Tonkin JD, Haase P, Bunzel-Drüke M, Zimball O, Scharf M, Stoll S (2017) Characterizing fish responses to a river restoration over 21 years based on species traits. Conserv Biol 31:1098-1108. https://doi.org/10.1111/cobi. 12908

Johnson SL, Rodgers JD, Solazzi MF, Nickelson TE (2005) Effects of an increase in large wood on abundance and survival of juvenile salmonids (Oncorhynchus spp.) in an Oregon coastal stream. Can J Fish Aquat Sci 62:412-424

Jones KK, Anlauf-Dunn K, Jacobsen PS, Strickland M, Tennant L, Tippery SE (2014) Effectiveness of instream wood treatments to restore stream complexity and winter rearing habitat for juvenile coho salmon. Trans Am Fish Soc 143:334-345

Jonsson B, Jonsson N (2011) Ecology of Atlantic Salmon and brown trout: habitat as a template for life histories. Springer, New York

Junge CO, Libosvarsky J (1965) Effect of size selectivity on population estimates based on successive removals with electric fishing gear. Zool Listy 14:171-178

Jungwirth M, Muhar S, Schmutz S (eds) (2000). Assessing the ecological integrity of running waters: proceedings of the international conference, held in Vienna, Austria, 9-11 November 1998. Reprinted from hydrobiologia, vol 422-423. Developments in Hydrobiology, Kluwer Academic Publishers, p 487

Kail J, Arle J, Jähnig SC (2012) Limiting factors and thresholds for macroinvertebrate assemblages in European rivers: empirical evidence from three datasets on water quality, catchment urbanization, and river restoration. Ecol Ind 18:63-72

Koljonen S, Huusko A, Mäki-Petäys A, Louhi P, Muotka T (2012) Assessing habitat suitability for juvenile Atlantic salmon in relation to in-stream restoration and discharge variability. Restor Ecol 21:344-352

Kondolf GM, Micheli ER (1995) Evaluating stream restoration projects. Environ Manag 19:1-15

Korsu K, Huusko A, Korhonen PK, Yrjänä T (2010) The potential role of stream habitat restoration in facilitating salmonid invasions: a habitat-hydraulic modeling approach. Restor Ecol 18:158-165

Laudon H, Buffam I (2008) Impact of changing DOC concentrations on the potential distribution of acid sensitive biota in a boreal stream network. Hydrol Earth Syst Sci 12:425-435

Lepori F, Palm D, Brännäs E, Malmqvist B (2005) Does restoration of structural heterogeneity in streams enhance fish and macroinvertebrate diversity? Ecol Appl 15:2060-2071

Lorenz AW, Feld CK (2013) Upstream river morphology and riparian land use overrule local restoration effects on ecological status assessment. Hydrobiologia 704:489. https:// doi.org/10.1007/s10750-012-1326-3

Lorenz AW, Stoll S, Sundermann A, Haase P (2013) Do adult and YOY fish benefit from river restoration measures? Ecol Eng 61:174-181. https://doi.org/10.1016/j.ecoleng.2013. 09.027

Louhi P, Mäki-Petäys A, Huusko A, Muotka T (2014) Resource use by juvenile brown trout and Alpine bullhead: influence of interspecific versus intraspecific competition. Ecol Freshw Fish 23:234-243

Louhi P, Vehanen T, Huusko A, Mäki-Petäys A, Muotka T (2016) Long-term monitoring reveals the success of salmonid habitat restoration. Can J Fish Aquat Sci 73:1733-1741. https://doi.org/10.1139/cjfas-2015-0546

Luhta P-L, Huusko A, Louhi P (2012) Re-building brown trout populations in dredged boreal forest streams: in-stream restoration combined with stocking of young trout. Freshw Biol 57:1966-1977

Mäki-Petäys A, Muotka T, Huusko A, Tikkanen P, Kreivi P (1997) Seasonal changes in habitat use and preference by juvenile brown trout Salmo trutta in a northern boreal river. Can J Fish Aquat Sci 54:520-530

Mäki-Petäys A, Erkinaro J, Niemelä E, Huusko A, Muotka T (2005) Spatial distribution of juvenile salmon in a subarctic river: size-specific changes in a strongly seasonal environment. Can J Fish Aquat Sci 61:2329-2338

Marttila M, Louhi P, Huusko A, Mäki-Petäys A, Yrjänä T, Muotka T (2016a) Long-term performance of in-stream restoration measures in boreal streams. Ecohydrology 9:280-289. https://doi.org/10.1002/eco.1634

Marttila M, Kyllönen K, Karjalainen TP (2016b) Social success of in-stream habitat improvement: from fisheries 
enhancement to the delivery of multiple ecosystem services. Ecol Soc 21:4

Miller BP, Sinclair EA, Menz MHM, Elliot CP, Bunn E, Commander LE, Dalziell E, David E, Davis B, Erickson TE, Golos PJ, Krauss SL, Lewandrowski W, Mayence CE, Merino-Martín L, Merritt DJ, Nevill PG, Phillips RD, Ritchie AL, Ruoss S, Stevens JC (2016) A framework for the practical science necessary to restore sustainable, resilient, and biodiverse ecosystems. Restor Ecol. https:// doi.org/10.1111/rec. 12475

Ministry of Agriculture and Forestry (2012) National fish passage strategy. Government Resolution 8.3.2012. p 30. In Finnish. http://mmm.fi/documents/1410837/1516655/1-4Kansallinen_kalatiestrategia2012.pdf/fae1c9f2-29084859-82ce-0b46c612f179. Accessed 30 Sept 2017

Mueller M, Pander J, Geist J (2014) The ecological value of stream restoration measures: an evaluation on ecosystem and target species scales. Ecol Eng 62:129-139

Muhar S, Januschke K, Kail J, Poppe M, Schmutz S, Hering D, Buijse AD (2016) Evaluating good-practice cases for river restoration across Europe: context, methodological framework, selected results and recommendations. Hydrobiologia 769:3-19. https://doi.org/10.1007/s10750016-2652-7

Muotka T, Syrjänen J (2007) Changes in habitat structure, benthic invertebrate diversity, trout populations and ecosystem processes in restored forest streams: a boreal perspective. Freshw Biol 52:724-737

National Research Council (1992) Restoration of aquatic ecosystems: science, technology, and public policy. The National Academies Press, Washington, DC. https://doi. org/10.17226/1807

Nilsson C, Lepori F, Malmqvist B, Törnlund E, Hjerdt N, Helfield JM, Palm D, Östergren J, Jansson R, Brännäs E, Lundqvist $\mathrm{H}$ (2005) Forecasting environmental responses to restoration of rivers used as log floatways: an interdisciplinary challenge. Ecosystems 8:779-800

Nilsson C, Polvi LE, Gardeström J, Hasselquist EM, Lind L, Sarneel JM (2015) Riparian and in-stream restoration of boreal streams and rivers: success or failure? Ecohydrology 8:753-764. https://doi.org/10.1002/eco.1480

Palm D, Brännäs E, Lepori F, Nilsson K, Stridsman S (2007) The influence of spawning habitat restoration on juvenile brown trout Salmo trutta density. Can J Fish Aquat Sci 64:509-515

Palmer MA, Ambrose RF, Poff NL (1997) Ecological theory and community restoration ecology. Restor Ecol 5:291-300

Palmer MA, Menninger HL, Bernhardt E (2010) River restoration, habitat heterogeneity and biodiversity: a failure of theory or practice. Freshw Biol 55:205-222

Polvi LE, Nilsson C, Hasselquist EM (2014) Potential and actual geomorphic complexity of restored headwater streams in northern Sweden. Geomorphology 210:98-118

Poppe M, Kail J, Aroviita J, Stelmaszczyk M, Giełczewski M, Muhar S (2016) Assessing restoration effects on hydromorphology in European mid-sized rivers by key hydromorphological parameters. Hydrobiologia 769:21. https:// doi.org/10.1007/s10750-015-2468-X
Rassi P, Hyvärinen E, Juslén A, Mannerkoski I (eds) (2010) The 2010 red list of Finnish species. The Ministry of the Environment \& SYKE, Helsinki, p 685

Roni P (2003) Responses of benthic fishes and giant salamanders to placement of large woody debris in small Pacific Northwest streams. North Am J Fish Manag 23:1087-1097

Roni P, Quinn TP (2001) Density and size of juvenile salmonids in response to placement of large woody debris in western Oregon and Washington streams. Can J Fish Aquat Sci 58:282-292

Roni P, Beechie TJ, Bilby RE, Leonetti FE, Pollock MM, Pess GR (2002) A review of stream restoration techniques and a hierarchical strategy for prioritizing restoration in Pacific Northwest Watersheds. North Am J Fish Manag 22:1-20

Roni P, Hanson K, Beechie T (2008) Global review of the physical and biological effectiveness of stream habitat rehabilitation techniques. North Am J Fish Manag 28:856-890

Roni P, Beechie TJ, Pess GR, Hanson K (2015) Wood placement in river restoration: fact, fiction, and future direction. Can J Fish Aquat Sci 72:466-478. https://doi.org/10.1139/ cjfas-2014-0344

Shuster JJ (2010) Empirical vs. natural weighting in random effects meta-analysis. Stat Med 29:1259-1265

Shuster JJ, Hatton RC, Hendeles L, Winterstein AG (2010) Reply to discussion of 'Empirical vs natural weighting in random effects meta-analysis'. Stat Med 29:1272-1281. https://doi.org/10.1002/sim.3842

Stewart GB (2010) Meta-analysis in applied ecology. Biol Lett 6:78-81

Stewart GB, Bayliss HR, Showler DA, Sutherland WJ, Pullin AS (2009) Effectiveness of engineered in-stream structure mitigation measures to increase salmonid abundance: a systematic review. Ecol Appl 19:931-941

Stoll S, Sundermann A, Lorenz AW, Kail J, Haase P (2013) Small and impoverished regional species pools constrain colonisation of restored river reaches by fishes. Freshw Biol 58:664-674. https://doi.org/10.1111/fwb.12068

SYKE (2013) The ecological status of Finland's large lakes is good but the coastal waters are in a poor condition. Newsletter of the Finnish Environment Institute SYKE. Envelope 3/2013. http://mmm.multiedition.fi/syke/ envelope/Envelope_2013_3/sivu_5.php. Accessed 26 June 2017

Syrjänen JT, Sivonen K, Sivonen O (2014) Redd counting in monitoring salmonids in Finnish inland waters. In: Carline RF, LoSapio C (eds) Wild trout XI: looking back and moving forward. Wild trout symposium, West Yellowstone, pp. 288-294, Bozeman, MT. p 392. http://www. wildtroutsymposium.com/proceedings-11.pdf. Accessed 16 Nov 2018

Syrjänen JT, Ruokonen T, Ketola T, Valkeajärvi P (2015) The relationship between stocking eggs in boreal spawning rivers and the abundance of brown trout parr. ICES J Mar Sci 72:1389-1398. https://doi.org/10.1093/icesjms/fsv017

Syrjänen JT, Vainikka A, Louhi P, Huusko A, Orell P, Vehanen T (2018) History, conservation and management of adfluvial brown trout stocks in Finland. In: Lobón-Cerviá J, Sanz N (eds) Brown trout: biology, ecology and management. Wiley, Hoboken, pp 697-733 
Thomas G, Lorenz AW, Sundermann A, Haase P, Peter A, Stoll $S$ (2015) Fish community responses and the temporal dynamics of recovery following river habitat restorations in Europe. Freshw Sci 34:975-990

Thompson MSA, Brooks SJ, Sayer CD, Woodward G, Axmacher JC, Perkins DM, Gray C (2018) Large woody debris "rewilding" rapidly restores biodiversity in riverine food webs. J Appl Ecol 55:895-904

Vehanen T, Huusko A, Mäki-Petäys A, Mykrä H, Louhi P, Muotka T (2010) Effects of habitat rehabilitation on habitat and brown trout in boreal forest streams. Freshw Biol 55:2200-2214

Vehanen T, Sutela T, Jounela P, Huusko A, Mäki-Petäys A (2013) Assessing electric fishing sampling effort to estimate stream fish assemblage attributes. Fish Manag Ecol 20:10-20

Viechtbauer W (2010) Conducting meta-analyses in R with the metafor package. J Stat Softw 36:1-48

Waldman J, Wilson KA, Mather M, Snyder NP (2016) A resilience approach can improve anadromous fish restoration. Fisheries 41:116-126

Ward DM, Nislow KH, Folt CL (2008) Do native species limit survival of reintroduced Atlantic salmon in historic rearing streams? Biol Cons 141:146-152

Ward DM, Hvidsten NA (2011) Predation: competition and context dependence. In: Aas $\varnothing$, Einum S, Klemetsen A, Skurdal J (eds) Atlantic Salmon ecology. Blackwell Publishing Ltd., Oxford, pp 199-220

White SL, Gowan C, Fausch KD, Harris JG, Saunders WC (2011) Response of trout populations in five Colorado streams two decades after habitat manipulation. Can J Fish Aquat Sci 68:2057-2063

Whiteway SL, Biron PM, Zimmerman A, Venter O, Grant JWA (2010) Do in-stream restoration structures enhance salmonid abundance? A meta-analysis. Can J Fish Aquat Sci 67:831-841

Yrjänä T (1998) Efforts for in-stream fish habitat restoration within the river Iijoki, Finland-goals, methods and the results. In: de Waal L, Large A, Wade M (eds) Rehabilitation of rivers: principles and implementation. Wiley, Sussex, pp 239-250

Zuur AF, Ieno EN, Walker NJ, Saveliev AA, Smith GM (2009) Mixed effects models and extensions in ecology with R. Springer, New York
References for studies and reports included in the analyses

Eloranta A, Olkio K (1987) Size, growth and density of brown trout (Salmo trutta L.) in the Arvajanjoki watercourse, Finnish lake District. Biol Res Rep Univ Jyväskylä 10:167-188

Eloranta A, Huovinen M, Jokinen A (1992) Simunankosken (Laukaa) kalataloudellinen kunnostussuunnitelma. KeskiSuomen vesi- ja ympäristöpiiri

Huolila M, Hyytinen L, Lähteenmäki R (2000) Virtavesien kalataloudellisten kunnostusten seuranta ja taimenen istutuskokeilut Mikkelin läänissä, p 36

Janatuinen A (2008) Espoon virtavesien sähkökoekalastukset. Espoon ympäristökeskus, p 32

Juntunen K, Paso J, Jokikokko E (2001) Lohi nousee Simojokeen, Kuivajokeen, Kiiminkijokeen ja Pyhäjokeen. Tuloksia ja päätelmiä vuosien 1999-2000 seurannoista. Kala- ja riistaraportteja 221

Jutila E, Karttunen V, Niemitalo V (1994) Parempi kivi koskessa kuin kymmenen rannalla: erilaisten kunnostusmenetelmien vaikutus taimenen poikasmääriin Iijoen sivujokien koskissa. Kalatutkimuksia 87:29

Lapin vesitutkimus Oy (2000) Iijoen yhteistarkkailu—vuoden 1999 kalataloustarkkailun tulokset

Nenonen S, Liljaniemi P (eds) (2007) Simojoen tila ja kunnostus-Simojoki-life. Suomen ympäristö 13

North Karelia TE Office (2001) Tietoja Pohjois-Karjalan virtavesien kalastuksesta. Maa- ja metsätalousministeriö. Kala- ja riistahallinnon julkaisuja 57:138

Seppänen O (1995) Virtavesien kunnostus Oulun vesi- ja ympäristöpiirin alueella vuosina 1988-1995. Pohjois-Pohjanmaan ympäristökeskus

Vihtonen M (2009) Herajoen kalataloudellinen kartoitus. Pielisen Järvilohi ja Taimen 2008-2010-hanke. p 31

Moilanen E, Luhta PL (2011) Iijoen kunnostettujen jokien kalataloudellinen seuranta 2005-2010. Metsähallituksen luonnonsuojelujulkaisuja B 159:110

Yrjänä T (1992) Uittoväylien entisöintiin liittyvä koskien kunnostus Iijoen sivuvesillä vuonna 1991. Oulun vesi- ja ympäristöpiiri

Publisher's Note Springer Nature remains neutral with regard to jurisdictional claims in published maps and institutional affiliations. 